\title{
Challenges, Coping Mechanisms and the Support Accorded to Student-mothers in Academic Pursuit: A Case Study of Egerton University, Nakuru County
}

\author{
Kiburi Racheal Kanana ${ }^{1,}$, Josephine Obonyo ${ }^{1}$, Charles Kamau Wambu ${ }^{2}$ \\ ${ }^{1}$ Institute of Women Gender and Development Studies, Egerton University, Nakuru, Kenya \\ ${ }^{2}$ Department of Community Development and Environmental Management, Cooperative University, Nairobi, Kenya \\ Email address: \\ kanaracheal@gmail.com (R. K. Kiburi), obonyojosephine@yahoo.com (J. Obonyo), ckamau@cuk.ac.ke (C. K. Wambu) \\ ${ }^{*}$ Corresponding author
}

\section{To cite this article:}

Kiburi Racheal Kanana, Josephine Obonyo, Charles Kamau Wambu. Challenges, Coping Mechanisms and the Support Accorded to Studentmothers in Academic Pursuit: A Case Study of Egerton University, Nakuru County. Advances in Sciences and Humanities.

Vol. 7, No. 3, 2021, pp. 93-101. doi: 10.11648/j.ash.20210703.17

Received: August 18, 2021; Accepted: August 31, 2021; Published: September 23, 2021

\begin{abstract}
Education is an important aspect in development as it strengthens nations and empowers people thus making it critical to Kenya's attainment of Vision 2030. Education benefits society, communities, and individuals across the globe. Today, there is a high number of student mothers in institutions of higher learning whereby the demands in academic pursuit conflicts with motherhood responsibilities thus affecting their academic performance. Despite the existence of guidelines and policies on return to school, student mothers continue to face challenges in pursuit for education. The aim of this study was to examine determinants of schooling challenges, coping mechanisms and the support accorded to student mothers in their pursuit for higher education. The study adopted role conflict theory. A cross-sectional survey research design was used for this study. The study population was 360 student mothers. Simple random sampling procedure was used to obtain a sample size of 101 respondents. The data was collected using interview schedules and semi structured questionnaires. The data was analyzed using descriptive statistics. From the study findings, $80 \%$ of the respondents reported that economic challenge was a hindrance to academic performance. The findings indicated that $92 \%$ of the respondents had time management hurdle with respect to lecture attendance, co- curricular activities, childcare responsibilities, and domestic chores, academic trips, taking the child to clinic, assignments submission, academic group discussions and academic trainings. About $96 \%$ of respondents agreed that they received family support to meet day to day expenses while learning. From the study findings this study proposes the loan award criteria by HELB should be revised to incorporate student mothers as special group of loan applicants. Greater institutional and family support should be encouraged in order to strengthen positive coping mechanisms by student mothers in dealing with unavailability of adequate financial and family support.
\end{abstract}

Keywords: Schooling Challenges, Coping Mechanisms, Support Accorded \& Student-Mothers

\section{Introduction}

Across the globe students' pregnancy has been regarded as major challenge to their education and consequently career development. Developed countries such as the United Kingdom, Australia and the United States of America have been ranked top in teenage pregnancy rates [1]. In the United States of America, specifically Pennsylvania in 2005 had 26,047 young mothers who were faced with motherhood challenges. According to Banda one million teenage girls become pregnant yearly in United Kingdom [2]. This is much higher as compared to Japan and nearly twice in Great Britain. In the United States, the rate of teenage child bearing has decreased from 96 births in 1950s per 1000 women of age 15 to 19 to 49 births in 1957 per 2000 women [3].

In Sub-Saharan Africa (SSA) countries such as South Africa, Uganda and Kenya, teenage childbearing is a major problem that leads to school dropouts among young girls [5]. According to Odejimi teenage pregnancy restricts young women from schooling thus not able to venture into 
economic spheres [6]. In Kenya teenage pregnancy rates is estimated to be 5.5 million which stand at $23 \%$ for girls between ages of 15 to 19 who give birth yearly [7]. Teenage childbearing tendencies in Kenya change with time according to the socio- economic status and geographical region. According to statistics Nairobi, Kakamega and Machakos counties are leading with teenage pregnancy [7]. The issue of school dropout among girls in Kenya, due to pregnancies is as old as the education system itself [6]. Despite the introduction of free primary and secondary education fewer girls are joining University education due to teenage pregnancy while others enroll as student mothers in the Universities [8].

Female student drop out of the University due to childbearing since it becomes quite expensive and time consuming to meet the two responsibilities, thus becoming an issue of interest in the country [9]. When a student mother drops out at the University level, the cost is much higher as compared to when she drops out at secondary school level due to expense accumulated over the years. Student mothers face several challenges such as time management which leads to role overload and role conflict which impacts negatively on her academics and as well as her wellbeing [10]. Combining motherhood and academics causes role conflict that poses a lot of challenges to student mothers therefore making them abandon one role for the sake of the other [11]. This role conflict brings about stress that an individual experience [12]. Stress is a specific collection of experiences and in response to these experiences one draws the coping mechanisms [13].

In Kenyan Universities, there is growing number of student mothers enrolling for higher education. However, a number of them face challenges in balancing their studies and multiple roles. Managing family roles and academics places student mothers at a significant implications on student mother's academic success. Some of the reasons for such challenges are that student mothers spend a lot of their time on childcare, household chores, thus affecting their performance academics, hence leading to delayed graduation or incomplete courses. Student mothers face difficulties in their undergraduate studies as they are likely to arrive late for classes, leave early or even miss classes. Having family and academics responsibilities make student mothers have unique needs that the University does not address. This uniqueness affects their ability to complete their academics with others. Therefore, there is a need to examine the challenges, coping mechanisms and the accorded support of student mothers in academic pursuit in Egerton University in Nakuru County, Kenya.

\section{Literature Review}

\subsection{Issues of Teenage Pregnancies Among Student in Kenya}

Pregnancy has been a major challenge to many girls dropping out of school in Kenya. A number of studies suggest that student pregnancy is associated with disruption of schooling, social disadvantage and an on-going cycle of poverty $[14,15]$. Despite worldwide acknowledgement of the value of female education, a large number of girls in Sub Saharan Africa (SSA) continue to have their school careers cut short by unwanted pregnancies and as a result suffer the negative social and psychological consequences that are derived from this situation [16].

According to Boyana and Morangi 44 percent of the women aged 15-19 years have had sexual encounters [17]. 70 percent of adolescents girls aged between 15-19 years engage in high risk unprotected sexual practices that lead to teenage pregnancies thus school dropouts. Rotich et al., revealed that female school students begin childbearing by age 18 in study findings of Maasai girls in Kenya [18]. Therefore, about 30 percent of all adolescent girls deal with issues of teenage pregnancy and school dropout [19].

Pregnancy and motherhood do not always interrupt education, but it does introduce a new set of circumstances that influence future decision to the girl's education [9]. Adolescent pregnancy can have a profound impact on the student mother and child by placing limits in her education pursuit, economic stability and family support [20]. This is because of how the society views and responds to the adolescent pregnancy rather than the pregnancy itself that push girls out of school and hampers their opportunities for educational and career development [7].

The academic pursuit of a student mother is at stake due to frequent absenteeism from school hence poor performance, re-sitting exams and school dropouts [5]. Student mothers face challenges upon re-entry and reintegration due to the responsibilities that come up with motherhood as well as studentship roles [21]. The learning environment becomes un-conducive as student mothers face ridicule, hostility and stigma from other student and the teachers. A number of girls are forced into marriage by their parents as a way legitimizing the child even when the girl is not ready to get into marriage [22]. This makes it hard for the girl to carry on with her studies as there is no support from the family both emotionally and financially. The study seeks to investigate on the challenges, accorded support and coping mechanisms of student mothers in academic pursuit; a case study of Egerton University.

\subsection{Academic Pursuit by Student Mothers in Universities}

According to Adu- Yeboah over the years there has been an increase in the enrolment of student mothers in higher learning institutions globally [23]. Today, student mothers are the fastest growing demographic in United States [24]. The African- America Institute projects a 15\% increase in female enrolment into institutions of higher learning by 2024 [25], much of which the National for Education Statistics claims will be comprised of student mothers (National Postsecondary Student Aids Study, 2015) seeking entrance into higher education degree [24].

In addition, about $20 \%$ of the undergraduate female students are estimated to be student mothers, without financial, emotional and physical support from parent, partners [11]. About $43 \%$ of the total student mothers are 
single student mothers [26]. Student mothers are a special population that requires different means of deliberation due to unique responsibilities and role strain [27]. The learning environment becomes difficult for student mothers who must schedule for child care and concentrating in academic pursuit. Mothering role is one of the most demanding activity which affects academic achievement of the most student mothers. In the study the researcher estimated how child nurturing responsibilities affects performance of under graduate student mothers.

\subsection{Challenges Faced by Student Mothers in Universities}

Student mothers face multiple challenges in balancing motherhood and academics hence lagging behind in access and participation in education [11]. Inability to cope with the demands of motherhood responsibilities coupled with academic demands brings about stress, poor health of student mothers, which negatively impacts their social and academic needs. All these factors contribute to poor performance, and delayed completion rates of student mothers [9]. Some of the challenges affecting student mothers include: time management and financial support challenge.

\section{Theoretical Framework}

\subsection{Role Conflict Theory}

This theory looks at gender patterns and relations and it argues that these patterns relates to certain social expectations which define proper behaviors for men and women. A key assumption of this theory is that all human beings behave in a way which is predictable and secondly all human beings learn roles with mutual expectation and recurring in social relations. This theory defines a role as a behavior expected of an individual who occupies a given social position, a mother therefore; a role is a comprehensive pattern of behavior's which is socially recognized. Role conflict occurs when there are incompatible demands placed upon a person such that compliance with both would be difficult. Persons experience role conflict when they find themselves pulled in various directions as they try to respond to the many statuses they hold. Role conflict can be something that can be either for a short period of time, or a long period of time, and it can also be connected to situational experiences [28].

\subsection{Motherhood Roles Conflicting with Academic Pursuit}

Conflict arises because of the desire of student mothers to succeed. However, the pressure exerted by motherhood responsibilities puts the student between two imposing and incompatible demands. According to Rosenthal, individual personality characteristics conflicts can arise within personality role conflict where "aspects of an individual's personality are in conflict with the other aspect of that same individual personality" [12]. Interpersonal relations can cause conflict because they are by definition having an association between two or more people that they may range from fleeting to enduring, which can cause that conflict. For instance, women in education especially in cases of higher learning, a mother can testify both parenting and school work which is done outside home and it is physically and emotionally draining.

With regard to this study, there are student mothers in Egerton University focused in academic success despite motherhood. Motherhood responsibilities and academics pose challenges to student mothers as both roles are demanding. For instance, student mothers may feel responsible for more than one role within this setting, and these roles may be disagreeable with each other. In such a case, it is evident that student mothers experience a great deal of conflict and strain while learning and at the same time trying to fulfill her family obligations. Therefore, there is need to investigate on the challenges of student mothers in their academic pursuit. This will help put on strategies that will improve the education life of student mothers.

\section{Methodology}

A cross-sectional survey research design was used for this study. The study was carried out in Egerton University main campus where there were many students mothers who are registered as mature entry and others admitted through Kenya University, Colleges and Central Placement Service (KUCCPS). The study population was 360 student mothers drawn from all the nine faculties (Faculty of Agriculture, Faculty of Arts and Social Science, Faculty of Commerce, Faculty of Education and Community Studies, Institute of women, gender and development studies, Faculty of Engineering and Technology, Faculty of Environment and Resource Development, Faculty of Science, \& Faculty of Health Sciences). Simple random sampling procedure was used to obtain a sample size of 101 respondents. Purposive sampling was used to sample the dean of students, student counsellors, director institute of women, gender and development studies and student leaders. The data was collected using interview schedules and semi structured questionnaires. The data was analyzed using descriptive statistics.

\section{Results and Discussion}

\subsection{Demographic Characteristics of the Respondents}

\subsubsection{Respondents' Age}

Majority $(72.3 \%)$ of the respondents were aged $18-27$

years, $24.8 \%$ of the total respondents were aged $28-37$ years, a few of the respondents were aged 38-47 years $(2.0 \%)$ and 48 years and above $(1.0 \%)$ according to the study.

From the study results $73 \%$ of the respondents were between 18-27 years. This is an indication that most of the respondents joined the University at the age of 18 as required by Kenya University and College Placement Services (KUCCPS). Respondents of ages 28 years and above reported to have joined university education after attending 
other levels of studies in others institutions thus joining the University as mature entry. From the study results all the student mothers were in their reproductive age of 18 years and above. Thus this age is termed as independent age since they are eligible to acquire national identification card. According to Adofo- Stella, the age of majority of female University students corresponds with their reproductive age
[11]. At the age of 18 , most of teenagers are sexually active and with minimal parental and adult supervision, the younger students are more likely to engage in irresponsible sexual relationships that are less informed on reproductive health issues and responsibilities. This makes them more vulnerable to unplanned pregnancies among other medical conditions leaving the female students with motherhood responsibilities.

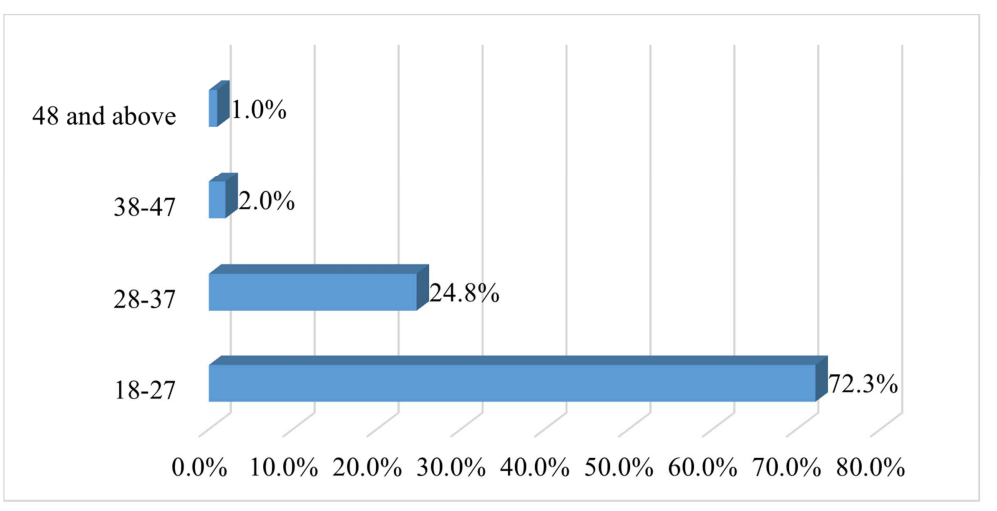

Figure 1. Respondents'Age Brackets.

\subsubsection{Marital Status of the Respondent}

Majority $(56.4 \%)$ of the respondents were single. About $34.7 \%$ of the respondents were married. A few respondents were separated $(7.9 \%)$ while others were widowed $(1.0 \%)$. This is summarized in Figure 2.

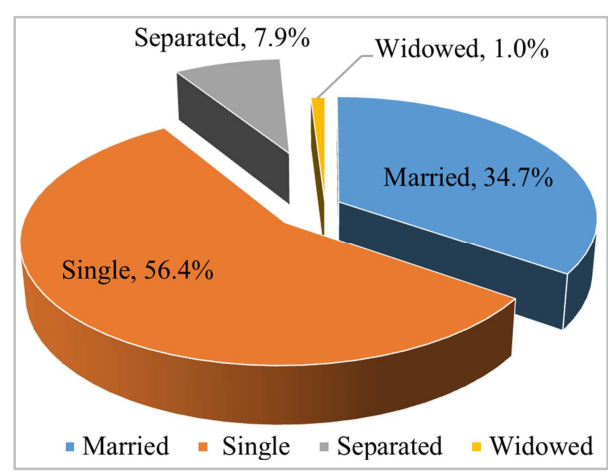

Figure 2. Marital Status.

From the study findings $56.4 \%$ of the student mothers were single as some were not ready to abandon their studies and get married. From key informants they reported that, "Single mothers were common since the student engaged into sexual act without prior knowledge of the consequences. Some of the boyfriends had abandoned them as they were not ready for responsibilities". On the other hand the married, separated and widowed were those that had joined the University education at a mature entry. They had acquired diploma from other institutions and needed to further their studies and some reported that they got married and later joined University education after nurturing their children.

Table 1. Number of dependents among the student mothers.

\begin{tabular}{llll}
\hline Number of children & Frequency & Percent & Cumulative Percent \\
\hline One & 80 & 79.2 & 79.2 \\
Two & 16 & 15.8 & 95.0 \\
Three & 2 & 2.0 & 97.0 \\
Four and above & 3 & 3.0 & 100.0 \\
Total & 101 & 100.0 & \\
\hline
\end{tabular}

Source: Field Data (2020)

The respondents reported that due to the burden of caring for a child they opted to have one child and do family planning. The results are consistent with [11] who found that most student mothers had one child during their academic pursuit due to the demanding roles of motherhood and academics. Those who were mature students had more than one child and had left them at home since some were enrolled and schooling. The counselor in the office of dean of student reported that, "due to parents' pressure in student mothers to take care of themselves majority have been able to avoid unprotected sex."

Table 2. Challenges faced by student mothers.

\begin{tabular}{|c|c|c|c|c|c|c|c|c|}
\hline Challenges & SA & $\mathbf{A}$ & $\mathbf{U}$ & D & SD & Total & Mean & Std. Dev. \\
\hline Food & $58(57.4 \%)$ & $36(35.6 \%)$ & $2(2.0 \%)$ & $5(5.0 \%)$ & $0(0.0 \%)$ & $101(100 \%)$ & 4.46 & 0.77 \\
\hline Shelter & $34(33.7 \%)$ & $42(41.6 \%)$ & $10(9.9 \%)$ & $11(10.9 \%)$ & $4(4.0 \%)$ & $101(100 \%)$ & 3.90 & 1.11 \\
\hline Clothing & $34(33.7 \%)$ & $46(45.5 \%)$ & $6(5.9 \%)$ & $14(13.9 \%)$ & $1(1.0 \%)$ & $101(100 \%)$ & 3.97 & 1.02 \\
\hline School fees & $56(55.4 \%)$ & $30(29.7 \%)$ & $4(4.0 \%)$ & $10(9.9 \%)$ & $1(1.0 \%)$ & $101(100 \%)$ & 4.29 & 1.00 \\
\hline Child upkeep & $67(66.3 \%)$ & $26(25.7 \%)$ & $0(0.0 \%)$ & $5(5.0 \%)$ & $3(3.0 \%)$ & $101(100 \%)$ & 4.48 & 0.95 \\
\hline
\end{tabular}

Source: Field Data (2020) 
From the study results, majority of the respondents strongly agreed $(57.4 \%)$ that food was a major challenge that student mothers face in their performance. Food is a major challenge to student mother because a child/ children required more nutritious and balanced meals that was not easily affordable, thus making it quite expensive for student mothers. Student mother had to engage income generating activities such as small business and others in order to raise money for child upkeep and other basic needs [11].

Moreover, majority of the respondents agreed that shelter was a major challenge that student mothers face in their performance as represented by $41.6 \%$ of the total responses. An additional $33.7 \%$ of the respondents strongly agreed that shelter was a hindrance to their performance. This was because at the end of each month student mother had to pay rent which is not available at most time due to provision of her own basic needs and that of the baby. It was basically a challenge for most student mothers as they lack source of income or employment hence surviving on the little support they get and loan from HELB. This study is in agreement with [29] that found out in their study that shelter was a major problem to many student mothers.

Most of the respondents agreed that clothing was a major challenge that student mothers face in their performance as represented by $45.5 \%$ of the total responses. An additional $33.7 \%$ of the respondents strongly agreed that clothing was a hindrance to their performance. Some respondents however disagreed (13.9\%) and strongly disagreed (1.0\%) while others were undecided (5.9\%). Despite clothing being a basic need, most student mothers struggled to provide clothing to their children as well as themselves. Most student mothers prefer buying second hand clothes because they are cheaper than the new ones. Others because of financial constraints cannot afford to buy enough clothes for themselves and their children too. This study concurs with the findings of [11] who found out that clothing was a major challenge for most student mothers.
Most of the respondents agreed that medical care was a major challenge that student mothers face in their performance $(38.6 \%$ of the respondents strongly agreed while $36.6 \%$ agreed). A few respondents disagreed (those who strongly disagreed were $2.0 \%$ and those who just disagreed were $15.8 \%)$. Others $(6.9 \%)$ were undecided about how medical care was a challenge to student mothers' performance. This is because when children were young, they were more susceptible to some diseases such as diarrhea, flu, common cold and other diseases that come as a result of poor feeding. They could easily contract respiratory diseases like pneumonia if exposed to a cold weather. All these makes the children unwell and the student mothers have to spend a lot of cash on medical bills which makes it a challenge to them.

Majority of the respondents strongly agreed (55.4\%) that school fees was a major challenge that student mothers face in their performance. An additional $29.7 \%$ of the respondents agreed that school fees was a major hindrance to the performance of student mothers. A few respondents disagreed $(9.9 \%)$ and strongly disagreed $(1.0 \%)$ while others were $\mathrm{s}$ undecided $(4.0 \%)$. This was an attributed to the fact that these student mothers had to cater for the needs of their children as well as their own needs. Therefore, the little they had they used to pay for school fees and sub-divided the rest to meet all others needs which include buying food, paying for their monthly rent, buying clothes as well as for paying medical bills which makes school fees payment a challenge [24].

\subsection{Coping Mechanism of Student Mothers in Academic Pursuit}

The respondents were asked how they coped with motherhood Challenges in their academic pursuit. The results as summarized in Table 3 .

Table 3. Coping Mechanisms against financial constraints.

\begin{tabular}{|c|c|c|c|c|c|c|c|c|}
\hline Coping mechanisms & SA & $\mathbf{A}$ & $\mathbf{U}$ & D & SD & Total & Mean & Std.Dev. \\
\hline Personal savings & $32(31.7 \%)$ & $29(28.7 \%)$ & $6(5.9 \%)$ & $6(5.9 \%)$ & $28(27.7 \%)$ & $101(100 \%)$ & 3.31 & 1.63 \\
\hline HELB & $30(29.7 \%)$ & $30(29.7 \%)$ & $0(0.0 \%)$ & $6(5.9 \%)$ & $35(34.7 \%)$ & $101(100 \%)$ & 3.14 & 1.71 \\
\hline Part-time employment & $8(7.9 \%)$ & $22(21.8 \%)$ & $7(6.9 \%)$ & $19(18.8 \%)$ & $45(44.6 \%)$ & $101(100 \%)$ & 2.30 & 1.43 \\
\hline Selling of food stuffs & $8(7.9 \%)$ & $16(15.8 \%)$ & $10(9.9 \%)$ & $19(18.8 \%)$ & $48(47.5 \%)$ & $101(100 \%)$ & 2.18 & 1.38 \\
\hline Work study programme in the university & $5(5 \%)$ & $31(30.7 \%)$ & $7(6.9 \%)$ & $16(15.8 \%)$ & $42(41.6 \%)$ & $101(100 \%)$ & 2.42 & 1.42 \\
\hline Cohabiting & $7(6.9 \%)$ & $14(13.9 \%)$ & $5(5 \%)$ & $22(21.8 \%)$ & $53(52.5 \%)$ & $101(100 \%)$ & 2.01 & 1.33 \\
\hline Using assets for loans (shylock) & $7(6.9 \%)$ & $11(10.9 \%)$ & $5(5 \%)$ & $20(19.8 \%)$ & $58(57.4 \%)$ & $101(100 \%)$ & 1.90 & 1.30 \\
\hline Betting & $5(5 \%)$ & $10(9.9 \%)$ & $5(5 \%)$ & $24(23.8 \%)$ & $57(56.4 \%)$ & $101(100 \%)$ & 1.83 & 1.20 \\
\hline Online writing for a fee & $15(14.9 \%)$ & $35(34.7 \%)$ & $9(8.9 \%)$ & $10(9.9 \%)$ & $32(31.7 \%)$ & $101(100 \%)$ & 2.91 & 1.52 \\
\hline Hawking of clothes & $8(7.9 \%)$ & $13(12.9 \%)$ & $11(10.9 \%)$ & $17(16.8 \%)$ & $52(51.5 \%)$ & $101(100 \%)$ & 2.09 & 1.36 \\
\hline Renting house temporary & $10(9.9 \%)$ & $23(22.8 \%)$ & $6(5.9 \%)$ & $17(16.8 \%)$ & $45(44.6 \%)$ & $101(100 \%)$ & 2.37 & 1.48 \\
\hline $\begin{array}{l}\text { Leaving the child with parents and friends while in } \\
\text { school }\end{array}$ & $40(39.6 \%)$ & $18(17.8 \%)$ & $8(7.9 \%)$ & $10(9.9 \%)$ & $25(24.8 \%)$ & $101(100 \%)$ & 3.38 & 1.65 \\
\hline Leaving the child at day care center & $38(37.6 \%)$ & $27(26.7 \%)$ & $5(5 \%)$ & $14(13.9 \%)$ & $17(16.8 \%)$ & $101(100 \%)$ & 3.54 & 1.52 \\
\hline Use of fake examination cards during exam period & $6(5.9 \%)$ & $6(5.9 \%)$ & $3(3 \%)$ & $15(14.9 \%)$ & $71(70.3 \%)$ & $101(100 \%)$ & 1.62 & 1.17 \\
\hline Making other student hair at a pay & $12(11.9 \%)$ & $14(13.9 \%)$ & $6(5.9 \%)$ & $8(7.9 \%)$ & $61(60.4 \%)$ & $101(100 \%)$ & 2.09 & 1.52 \\
\hline
\end{tabular}




\begin{tabular}{|c|c|c|c|c|c|c|c|c|}
\hline Coping mechanisms & SA & A & $\mathbf{U}$ & D & SD & Total & Mean & Std.Dev. \\
\hline Deferment of studies & $4(4 \%)$ & $13(12.9 \%)$ & $6(5.9 \%)$ & $19(18.8 \%)$ & $59(58.4 \%)$ & $101(100 \%)$ & 1.85 & 1.23 \\
\hline Cost sharing on a rented house & $14(13.9 \%)$ & $13(12.9 \%)$ & $3(3 \%)$ & $13(12.9 \%)$ & $58(57.4 \%)$ & $101(100 \%)$ & 2.13 & 1.54 \\
\hline Night club dances & $3(3 \%)$ & $1(1 \%)$ & $1(1 \%)$ & $13(12.9 \%)$ & $83(82.2 \%)$ & $101(100 \%)$ & 1.30 & 0.81 \\
\hline
\end{tabular}

Source: Field Data (2020)

From study results majority of the respondents agreed that HELB was a key coping mechanism that student mothers implemented against financial constraints in their academic life $(29.7 \%$ of the respondents strongly agreed while $29.7 \%$ agreed). Some few respondents disagreed (5.9\%) and strongly disagreed $(34.7 \%)$ that HELB was an important coping mechanism against financial constraints faced by students in their academic pursuit. Others (0\%) were undecided about coping mechanism through HELB among student mothers. Majority of the respondents agreed that HELB helped student mothers in meeting some of their economic needs. This is because HELB loan was some amount of money that was deposited in the student account thus able to account for each as every coin without any restrictions and they were able to live by the budget.

From the study results majority of the respondents disagreed that part-time employment was not a coping mechanism that student mothers implemented against financial constraints in their academic life $(44.6 \%$ of the respondents strongly disagreed while $18.8 \%$ disagreed). Some few respondents agreed $(21.8 \%)$ while others strongly agreed $(7.9 \%)$ that part-time employment was an important coping mechanism against financial constraints faced by students in their academic pursuit. Others were undecided (6.9\%) about coping mechanism through part-time employment among student mothers. Many of the respondents disagreed that part time employment was not a coping mechanism because they had tight schedule for academics and the childcare responsibilities. Those that agreed were those were much well off and they could afford to employ a house help who would help around with domestic chores and some of the childcare responsibilities.

In this study, most of the respondents disagreed that selling of food stuffs was not a coping mechanism that student mothers implemented against financial constraints in their academic life $(47.5 \%$ of the respondents strongly disagreed while $18.8 \%$ disagreed). Some few respondents agreed $(15.8 \%)$ while others strongly agreed $(7.9 \%)$ that selling of food stuffs was not an important coping mechanism against financial constraints faced by students in their academic pursuit. Others were undecided (9.9\%) about coping mechanism through selling of food stuffs among student mothers. Majority of the respondents disagreed that selling food stuffs was not a coping mechanism. This was because purchasing those required money that student mothers did not have. They also did have time to sell as most of the time was consumed by academics and childcare responsibilities.

Most of the respondents disagreed that work study programme in the university was not a coping mechanism that student mothers implemented against financial constraints in their academic life $(41.6 \%$ of the respondents strongly disagreed while $15.8 \%$ disagreed). Some few respondents agreed $(30.7 \%)$ while others strongly agreed $(5 \%)$ that work study programme in the university was an important coping mechanism against financial constraints faced by students in their academic pursuit. Others were undecided $(6.9 \%)$ about coping mechanism through work study programme in the university among student mothers. For this study most of the respondents disagreed that work study programme was not a coping mechanism because in the University it does not use any specific criteria to select student for work study. Therefore, student mothers would apply and lack a chance to work while a few that got a chance lacked time to work due to childcare and academic responsibilities.

From the study results most of the respondents disagreed that cohabiting was a coping mechanism that student mothers implemented against financial constraints in their academic life $(52.5 \%$ of the respondents strongly disagreed while $21.8 \%$ disagreed). Some few respondents agreed $(13.9 \%)$ while others strongly agreed $(6.9 \%)$ that cohabiting was an important coping mechanism against financial constraints faced by students in their academic pursuit. Others were undecided (5\%) about coping mechanism through cohabiting among student mothers. From the results of the study majority of the respondents were single student mother who juggled motherhood responsibilities and those of academic by themselves.

Most of the respondents disagreed that using assets for loans (shylock) was not a coping mechanism that student mothers implemented against financial constraints in their academic life $(57.4 \%$ of the respondents strongly disagreed while $19.8 \%$ disagreed). Some few respondents agreed $(10.9 \%)$ while others strongly agreed $(6.9 \%)$ that using assets for loans (shylock) was not an important coping mechanism against financial constraints faced by students in their academic pursuit. Others were undecided (5\%) about coping mechanism through using assets for loans (shylock) among student mothers. From the results respondents reported that asserts for loan was not a coping mechanism. This was because most of the respondents did not have asserts that they would use for loans.

\subsubsection{Family Support for Student Mothers}

Respondents were asked if they received any form of family support and the results presented in Figure 3.

Majority of the respondents agreed that they were accorded family support as represented by $96.0 \%$ of the total responses. It was just $4.0 \%$ of the respondents who were not accorded family support. Most agreed that they received family support that played a major role in their academics completion and child well-being. 


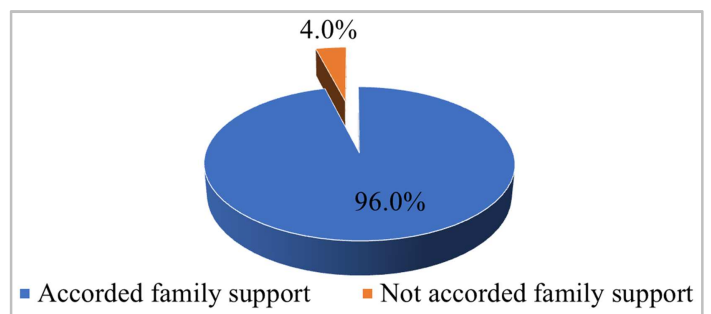

Figure 3. Family Support.

Respondents indicated to have received various forms of family support as depicted in Figure 4.

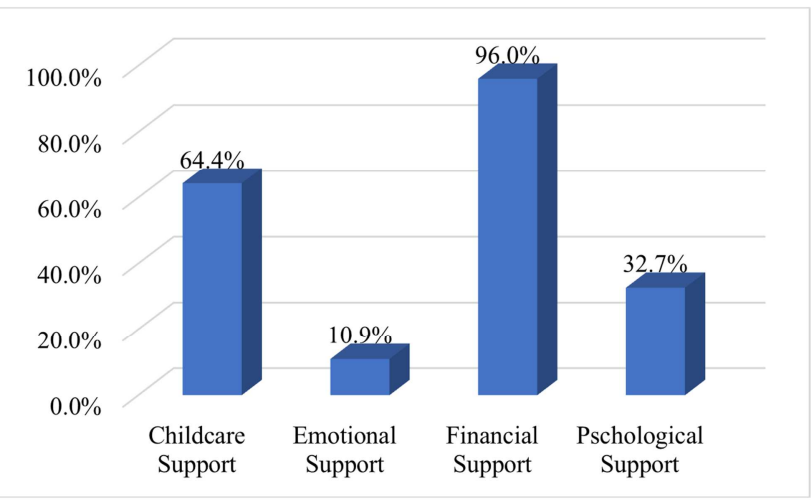

Figure 4. Forms of Family Support.

From the results of the study, majority of the respondents indicated to have received financial and childcare support as represented by $96.0 \%$ and $64.4 \%$ of the responses, respectively. Other respondents received psychological $(32.7 \%)$ and emotional support $(10.9 \%)$. This is because parents uphold and support education for girls more positively. Parents also facilitate the girls learning at home, encourage, continuous follow up and motivate them to score better academically. However, this varies from family to family, for instance a study by [30], noted that student mothers of parents with low educational attainment, occupation and income are more likely to withdraw support or minimize what they were normally giving in the sense that their daughter is married, which at most occasions is the opposite thus affecting her education.

\subsubsection{Institutional Support for Student Mothers}

Respondents were asked I they received any form of institutional support and the results presented in Table 4.

Table 4. Institutional support.

\begin{tabular}{lll}
\hline Institutional support & Frequency & Percent \\
\hline Guidance and counselling & 59 & 58.4 \\
Social support & 26 & 25.7 \\
Work study support & 7 & 6.9 \\
Time scheduling for classes & 2 & 2.0 \\
Childcare support & 3 & 3.0 \\
Spiritual support & 2 & 2.0 \\
Education support & 2 & 2.0 \\
Housing & 0 & 0.0 \\
Scholarships & 0 & 0.0 \\
Business Tenders & 0 & 0.0 \\
\hline
\end{tabular}

\begin{tabular}{lll}
\hline Institutional support & Frequency & Percent \\
\hline Food supplies & 0 & 0.0 \\
Medical & 0 & 0.0 \\
Total & 101 & 100.0 \\
\hline
\end{tabular}

Source: Field Data (2020)

From the study results, majority of the respondents indicated to benefit from guidance and counselling services from the institution as represented by $58.4 \%$ of the total responses. About $25.7 \%$ of the respondents indicated to receive social support services. Other services that were received by student mothers from the institution included work-study support $(6.9 \%)$, childcare support $(3.0 \%)$, time scheduling for classes $(2.0 \%)$, spiritual support $(2.0 \%)$ and education support (2.0\%). Some types of institutional support (housing, scholarships, business tenders, food supplies and medical) were never received.

From this study majority of student mothers were undergoing a hell of time with motherhood responsibilities combined with that of education. Therefore all what the respondents needed is someone to talk to them and assure them that it is possible. This study agrees with [31] who found that Higher Education Institutions support to student mothers plays an important role in the academic success of students and the perceptions of their experiences as whole. However, other institutional support such as housing, food supplies, child upkeep and medical expenses for the baby were not provided. Therefore, majority of the student mothers resided outside the university which excludes them from what is offered. This study agrees with [32] who found out that majority of the student mothers reside outside the campus which excludes them from the engagement in the residential aspect of the institution. In addition it was that the handbook of Egerton University, recommends that expectant student vacate the university halls of residence three months before delivery: 'since pregnancy disrupts academic performance' [33].

According to Flores the necessity of diverse institution support was reported to promote the persistence of student mothers completing academics especially students with special needs [34]. Student mothers navigate life in multiple roles of academic pursuit and family obligations. The results from key informant interviews revealed that institutional support was available, though in few ways and to limited number of students. One of the key informant had this to say:

Guidance and counselling, social support and work-study support programmes are the main forms of institutional help that is available to student mothers. The delivery mechanism of this support is however wanting since majority of the students are not able to access this kind of support.

\section{Conclusion and Recommendation}

Some of the major factors that affect student mothers' performance in the university include economic challenges (child upkeep, food and school fees) and time management hurdle with respect to lecture attendance, co- curricular activities, childcare responsibilities, domestic chores, 
academic trips, taking the child to clinic, assignments submission, academic group discussions and academic trainings.

Most student mothers at the University received economic/financial and childcare support from HELB and parents (mothers and fathers). Other student mothers also received psychological and emotional support. Majority of student mothers did not receive any institutional support to enable them smoothly continue with their education.

Due to unavailability of adequate economic and family support to student mothers, most of them resulted to a variety of coping strategies such as leaving of children elsewhere (at day care center, parents and friends) while in school, use of personal savings/HELB funds, online writing for a fee and work study programme in the university.

In view of the findings and the conclusion drawn above, the study recommends that; a special directorate/office is needed to help address the specific need of student mothers towards their performance. Due to the uniqueness of student mothers' needs, such directorate could better address the factors that affect the performance of the student mothers such as economic challenges (child upkeep, food and school fees) and time management. It is important that new students should be sensitized about family planning during orientation in order to avoid numerous challenges that are associated with responsibilities of motherhood while continuing with academic life. Secondly, the loan award criteria by HELB should be revised to incorporate student mothers as special group of loan applicants. There should be effort to increase the loan limits of student mothers in order to supplement the little support that these student receive from their parents (mothers and fathers). The additional loan amount could go a long way in enabling these special groups of students to smoothly continue with their education.

More importantly greater institutional and family support should be encouraged in order to strengthen positive coping mechanisms by student mothers in dealing with unavailability of adequate economic and family support. An institutional managed day care center should also be established in a bid to address major time management challenges that most student mothers face.

\section{References}

[1] Mosher, W., Jones, J. \&Abma, J. (2012). Intended and unintended births in the United States $1982-2010$. National Center for Health Statistics. Vita Health Stat (55). P. 1-28.

[2] Banda, P. (2015). Education First, Pregnancy Later. http://www.daily- mail.com. Retrieved on 07-09-2019.

[3] Kearney, M. \& Levine, P. (2012). Why is teen birth rate in the United State so high and why does it matter? J Econ prospect 26 (2): 141-63.

[4] Koski, A., Clarks, S. \& Nandi, A. (2017). Has a Child Marriage Declined in Sub - Saharan Africa? An analysis of Trends in 31 countries Population and Development Review 43 (1). 7-29.
[5] Bhana, D., Morrell, R. \& Shefer, T. (2010). South African teachers' responses to teenage pregnancy and teen-age mothers in schools. Culture, Health \& Sexuality 12 (8): 871883.

[6] Odejimi O., Fuller, P. \& Bellingham-Young, D. (2011). Determinants of teenage pregnancy in Africa: Iimplication for public health policy and practice. American Economic Journal: Applied Economics. 3: 1-34.

[7] United Nations Children's Fund (UNICEF, 2016). The state of world's children 2016: a fair chance for every child. New York, Harry Potter publisher.

[8] Chemnjor, P. (2013). Against all Odds: student parents in public universities: Nairobi, University of Nairobi.

[9] Sheila, M. (2018). Pride and hope, shame and blame: How Welfare Mothers in Higher Education juggle competing Identities, in Tiffan, Taylor, Katrina Bloch (ed). Marginalized mothers, mothering from the margins (Advances in Gender Research, volume 25). Emerald Publishing limited, 11-24.

[10] Williams, N. (2012). Motherhood in childhood. Facing the challenges of Adolescent pregnancy. UNFPA state of World Population 2013, UNFPA.

[11] Adofo-Stella, A. (2013). Challenges and Coping Strategies of Student Nursing Mothers in Tertiary Institutions; Greater Accra Region of Ghana. Master of Philosophy Dissertation, University of Ghana, Legon.

[12] Rosenthal, R., Kahn, R. \& Wolfe, D. (2010). Organizational stress: studies in role conflict and ambiguity. University of Bedfordshire, UK. Williams, N. (2012). Motherhood in childhood. Facing the challenges of Adolescent pregnancy. UNFPA state of World Population 2013, UNFPA.

[13] Schneider, M. \& Deane, K. (Eds.). (2015). The university next door: What is a comprehensive university, who does it educate, and can it survive? New York, NY: Teachers College Press. Sciences: Theory and Practice, 15, 565-573.

[14] Sedge, G., Finer, L., Bankole, A. \& Simgh, S. (2015). Adolescent pregnancy, birth and abortion rates across countries: levels and recent trends. Journal of Adolescent Health 56 (2). 223-230.

[15] Maeke, E. (2013). Technical training institutes School Dropout in Kilome Division, Makueni District, Kenya. Unpublished Med Thesis, Kenyatta Technical training institutes.

[16] Bayona, M. \& Murangi, K. (2012). Botswana's Pregnancy Related Educational Policies and Their Implications on Expregnant Girls Education and Productivity: A bridged research report No 16. Nairobi: Academy Science Publishers.

[17] Kenya Bureau of Statistics. [KNBS]. (2016). Economic Survey 2016. Nairobi: Government Press.

[18] Rotich, K., Kipkirui, J. \& Mutisya, S. (2014). University Education of the Maasai Girls in Kenya at Crossroad. A viewpoint of the role local leaders and socio- cultural factors. The International Journal of Socio Science and Humanities Invention 1 (1). 51-61.

[19] Brown, G. (2010). The Intersectionality of Race, Gender and Re-entry: Challenges for African-American Women. New York, USA: American Constitution Society. 
[20] Eliza, J. (2012). Women's Education in Sub- Saharan Africa; Obstacles Facing Women and Girls Access to Education. Kenya Studies Review 1 (2), 57-71.

[21] Wasanga, P., Ogle, M. \& Wambua, R. (2011). Progress in gender equality in education: Kenya. SACMEQ (Policy Brief No. 6). Nairobi: Kenya National Examinations Council.

[22] Wekesa, A. (2010). Bending the private-public gender norms: negotiating schooling for young mothers from low income households in Kenya. Unpublished master's thesis, Institute of Social Studies. The Hague, The Netherlands.

[23] Adu-Yeboah, C. (2015). Mature Women Students Experiences of Social and Academic Support in Higher Education; A systematic review. Journal of Education and Training, 2 (2), 145-12.

[24] Freeman, A. (2015). Single Moms and Welfare Woes: A Higher Education Dilemma. The Atlantic, 18.

[25] The African- America Institute. (AAI). State of Education in African Report. (2015). A report card on the progress, opportunities and challenges confronting the African Education Sector. New York: The Africa- America Institute (AAI).

[26] Institute for Women's Policy Research. (March, 2014). Briefing paper. College students with children are common and face many challenges in higher education. www.iwpr.org/.

[27] Ms. Foundation for Women. (2013). More to do: the road to equality for women int he United States. Brooklynn, NY: Ms. Foundation for Women.

[28] Gerber, L. \& Macaronis, J. (2010). Sociology ( $7^{\text {th }}$ Canadian ed.). Pearson Canada. P. 129.

[29] Goldrick-Rab, S. \& Sorenson, K. (Fall 2010). Unmarried parents in college. The Future of Children. Princeton University (20) 2179-203.

[30] Lipman, E. (Fall, 2010). Understanding how education/support groups help lone mothers. BMC Public Health. 10 (4).

[31] Harmon, M. (2013). The impact of institutional support services, policies, and programs on the completion and graduation of African American students enrolled at select two-year colleges in Ohio. University of Toledo. India. https://cdn.americanprogress.org/wpcontent/uploads/2014/09/FloresCaseStudybrief.pdf.

[32] Reay, D., Crozier, G. \& Clayton, J. (2010). 'Fitting in' or 'standing out': Working-class students in UK higher education. British educational research journal, 36 (1), 107-124.

[33] Egerton University. (2004). Student handbook. Nairobi, Egerton University Press.

[34] Flores, A. (2014). How public universities can promote access and success for all students. Retrieved from Center for American Progress website. 